American Journal of Animal and Veterinary Sciences 4 (1): 21-25, 2009

ISSN 1557-4555

(C) 2009 Science Publications

\title{
Secretary IgA Concentrations and plasma Cell Count Changes Associated with the Estrous Cycle in Ewes
}

\author{
${ }^{1}$ Morteta H. AL-Medhtiy, ${ }^{1}$ A.B.Z. Zuki, ${ }^{2}$ M.M. Noordin and ${ }^{3}$ S. Agungpriyono \\ ${ }^{1}$ Department of Veterinary Preclinical Studies, Faculty of Veterinary Medicine, \\ University Putra Malaysia, 43400 Serdang, Selangor, Malaysia \\ ${ }^{2}$ Department of Veterinary Pathology and Microbiology, Faculty of Veterinary Medicine, \\ Bogor Agricultural University (IPB), Bogor 16680, Indonesia \\ ${ }^{3}$ Department of Anatomy, Physiology and Pharmacology, Faculty of Veterinary Medicine, \\ Bogor Agricultural University (IPB), Bogor 16680, Indonesia
}

\begin{abstract}
Problems statement: The level of uterine Secretory-IgA (S-IgA) and numbers of plasma cells was measured to observe the differences between two stages of estrous cycle (follicular and luteal phase) in the healthy cycling non pregnant ewes. Approach: Twelve ewes were used in this study and they were divided into two groups of 6 animals each according to the stages of estrous cycle. All ewes were subjected to estrous synchronization and allowed to undergo one natural estrous cycle after the removal of the sponge. All animals were then slaughtered at the end of the experiment. The uterine mucus was collected by flushing with a mixture of protease inhibitor cocktail in distilled water. For both stages, the level of uterine S-IgA was quantified by using ELISA and Methyl Green Pyronine staining was used to observe the plasma cell in the tissues of the uterine horn and oviduct of ewe's genital tract. Results: The results were analyzed by independent sample t-test and presented as mean \pm SEM. This study showed the relationship of the estrous cycle stages to uterine S-IgA concentration $\left(\mu \mathrm{g} \mathrm{mL}^{-1}\right)$ and populations of plasma cell in the healthy non-pregnant cycling ewes. The concentration $\left(\mu \mathrm{g} \mathrm{mL}^{-1}\right)$ of S-IgA $(0.20 \pm 0.01)$ in the follicular phase was highly significant $(\mathrm{p}<0.01)$ as compared with the luteal phase $(0.17 \pm 0.002)$. In addition, the populations of the plasma cells were significantly higher $(\mathrm{p}<0.01)$ in the uterine horn $(4.97 \pm 0.32)$ and oviduct $(3.82 \pm 0.33)$ during follicular phase compared to the luteal phase $(3.87 \pm 0.30)$ and $(1.90 \pm 0.21)$, respectively. Conclusion: The main reason for the immunosuppression during the luteal phase did not fully justified, especially with the presence of potential acquired infection during coitus in the follicular phase and at the same time immune system should decrease accordingly to prevent newly attached fetus rejection by the mother immune system.
\end{abstract}

Key words: S-IgA, plasma cells, estrous cycle, uterine lavage, ewes

\section{INTRODUCTION}

Immunoglobulin (Ig)-producing cells are quantitatively the most important humoral immune system in the body. Immunocytes, namely the B-cell blasts and plasma cells are found in all exocrine tissue sites, are mainly responsible for the synthesis of dimmers and larger polymers such as $\operatorname{IgA}(\mathrm{plgA})^{[3]}$. Secretary Component (SC) was synthesized by epithelial cells which have ability to transport the S-IgA as polymeric Immunoglobulin (PIgA) by polymeric Ig receptor $(\mathrm{PIgR})^{[2,7]}$.

The mucosal immune system, $\operatorname{IgA}$ and $\operatorname{IgG}$ in the female reproductive tract varies according to the estrous cycle stages, an effect attributed to the sex hormones ${ }^{[21]}$. The levels of immunoglobulins (A and $\mathrm{G}$ ) and antigensspecific antibodies in the genital tract of women and rhesus macaque vary with the menstrual cycle ${ }^{[16]}$. In sheep, uterine immune function seems to be differentregulation during different stage of estrous cycle and in the ovariectomized ewes ${ }^{[5,15,20,22]}$. Presence of the plasma cells is influenced by sex hormones in the endometrium of the sow and rat $^{[12,24]}$. The sow genital tract is suffering significant changes, where exceed in the estrous phase and still lower in the diestrus of the cycle $^{[12]}$. This study was conducted with the aims to quantify the S-IgA concentration levels in the uterine secretion and to quantify the population of plasma cells

Corresponding Author: Assoc. Prof. Dr Md Zuki Abu Bakar, Head Dept. of Veterinary Preclinical Sciences, Faculty of Veterinary Medicine, University Putra Malaysia (UPM). Malaysia 
throughout lamina propria of uterine horn and oviduct of healthy non-pregnant cycling ewes during the estrous cycle stages.

\section{MATERIALS AND METHODS}

Animals: Twelve healthy non-pregnant cycling local breed ewes with age between 11-13 months old and body weight of $16 \pm 2.6 \mathrm{~kg}$ were used in this study. All the animals were kept under natural lighting and feeding. The protocol of the study was approved by the Faculty's animal care and use committee (animal utilization protocol number: 08R26/Jun 08-May 09). The animals were divided into two groups (follicular and luteal phase; 6 ewes for each) after synchronization of the estrous cycle by insertion of sponges that contained $40 \mathrm{mg}$ flugestone acetate for 14 days. Pregnant Mare Serum Gonadotropin (PMSG) (Folligon ${ }^{\circledR}$ ) were given (400 IU) intramuscularly at sponge removal. The animals were allowed to undergo one natural estrous cycle after the removal of the sponge.

All the animals were euthanased and the reproductive tracts were collected. The stage of the estrous cycle (follicular and luteal phases) was determined by the signs of estrous exhibited by the ewes. Further more, confirmed by morphological and histological evaluation of the ovary and endometrial layers of reproductive tract. Morphologically, appearance of ovarian follicles $>5 \mathrm{~mm}$ refers to follicular phase or rising of the mature corpus luteum intimate to luteal phase of ewe's estrous cycle ${ }^{[18]}$. Histologically, straight and narrow tubular glands of the endometrium were observed during follicular phase, but the presence of the corpus luteum with typical secretory endometrium and the uterine glands begin secretion, dilating and becoming coiled were observed during luteal phase ${ }^{[1]}$.

Collection of uterine lavage fluids: The uterine lavage fluids were collected by flushing each genital tract with $5 \mathrm{~mL}$ of distilled water containing protease inhibitors cocktail (Sigma-Aldrich, USA). Uterine lavage fluids were centrifuged $\left(12000 \times \mathrm{g}\right.$ for $5 \mathrm{~min}$ at $\left.0^{\circ} \mathrm{C}\right)$ and frozen at $-80^{\circ} \mathrm{C}$ until assayed ${ }^{[16]}$. S-IgA concentration was measured by enzyme-linked immunosorbent assay $(\text { ELISA) })^{[14]}$.

Elisa: S-IgA was assayed using standard direct ELISA system $^{[6]}$. Ninety six-well flat bottom high binding ELISA microplates (Greiner Bio-One, Germany) were coated with replicate optimal concentrations of samples diluted in PBS and incubated overnight at $4{ }^{\circ} \mathrm{C}$. The plates were washed three times in PBS containing $0.05 \%$ Tween-20 and blocked with 5\% Bovine Serum Albumin (BSA; Merck, Germany) for $2 \mathrm{~h}$ at $25^{\circ} \mathrm{C}$. The plates were then washed three times. The plates were incubated with bound rabbit anti-sheep IgA: HRP (Horseradish Peroxidase) (AbD Serotec, UK) 1: 10000 for $2 \mathrm{~h}$ at $25^{\circ} \mathrm{C}$. The plates were washed again three times, the color developed with ABTS (2, 2', azino-bis (3-ethyl benzathiazoline-6-sulphonic acid)/H2O2 substrate (KPL, USA) was measured after $15 \mathrm{~min}$ at $414 \mathrm{~nm}$ on a Microtiter-Plate ELISA Reader (BIOTEK, USA).

Collection and staining of tissues: The uterine horns and oviducts were immediately collected (after the flashing) and fixed in 10\% formaldehyde in PhosphateBuffered Saline (PBS) (pH7.4). The tissues were processed for paraffin embedding and preparations of the sections were done according to histological protocol. Methyl Green-Pyronine (Sigma, USA) staining was used to detect of plasma cells in the tissue sections $^{[18]}$.

Plasma cells counting: The plasma cells were counted by using light microscopy (Olympus BX51, Japan) equipped with an image analyzer (Analysis LS Research). Enumeration of plasma cells was done based on five microscopic fields per section (under $40 \times$ magnifications) in three serial sections ${ }^{[11]}$. Only plasma cells in the lamina propria of the uterine horn and the oviduct ampulla were enumerated in this study.

Statistical analysis: S-IgA concentrations during the luteal and follicular phases were compared using the Independent sample t-test procedure and presented as mean \pm SEM. Plasma cell counts were compared across cycle phases using a non-parametric Mann Whitney test $^{[19]}$. All statistical procedures were conducted at $95 \%$ confidence interval.

\section{RESULTS}

S-IgA concentration in the uterine secretion: This experiment showed the relationship of the estrous cycle stages to the concentration of uterine S-IgA in the ewes as shown in Fig. 1. The mean S-IgA concentrations of all uterine lavage fluids during follicular phase $\left(0.20 \pm 0.01 \mu \mathrm{g} \mathrm{mL}^{-1} ; 95 \% \mathrm{CI}=-0.05\right.$ to -0.01$)$ were highly significant $(\mathrm{p}<0.01)$ than during the luteal phase $\left(0.17 \pm 0.002 \mu \mathrm{g} \mathrm{mL}^{-1}\right)$. 
American J. Animal \& Vet. Sci., 4 (1): 21-25, 2009

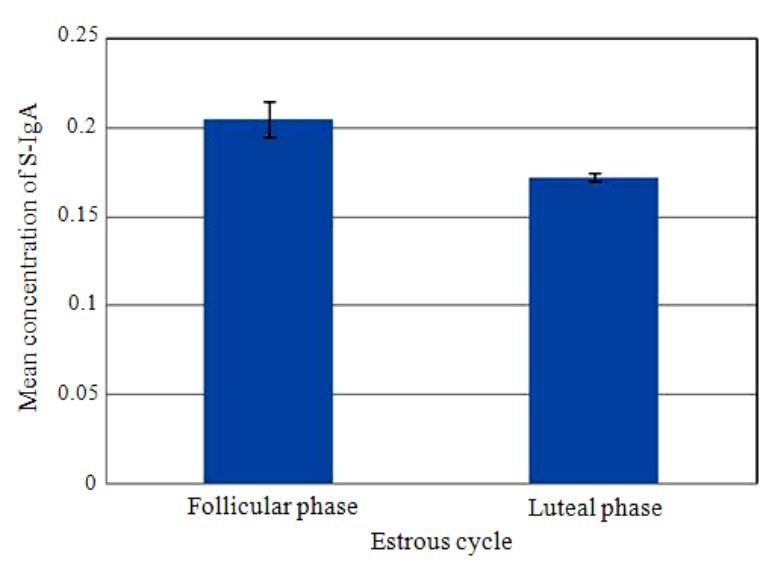

Fig.1: Mean concentration $\left(\mu \mathrm{g} \mathrm{mL}^{-1}\right)$ of uterine S-IgA by ELISA during follicular and luteal phase of ewe's estrous cycle

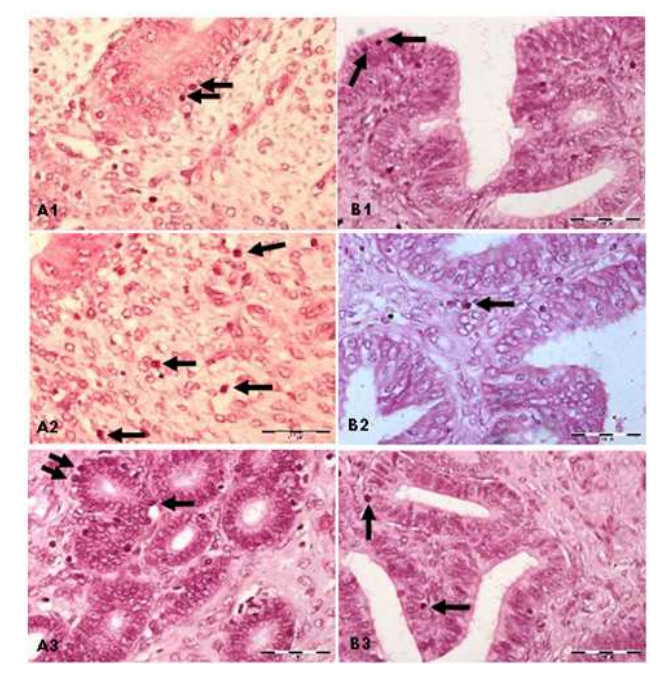

Fig. 2: A1, A2, A3 shows the plasma cells are localized throughout the lamina propria of the uterine horn sections. B1, B2, B3 shows it's localized throughout the lamina propria of the oviduct sections. Stain: Methyl Green Pyronine. $40 \times$ magnification

Plasma cells population: The sections of the uterine horn and oviduct stained with Methyl Green Pyronine are showed in Fig. 2. The plasma cells were identified by their basophilic cytoplasm and an eccentrically located nucleus with the special arrangement of the heterochromatin in a characteristic of cartwheel appearance. The plasma cells were located in the basal region of the epithelium for both of anatomical regions (A1, B1). Some were presented in the stroma that supports the epithelial layer for uterine horn and

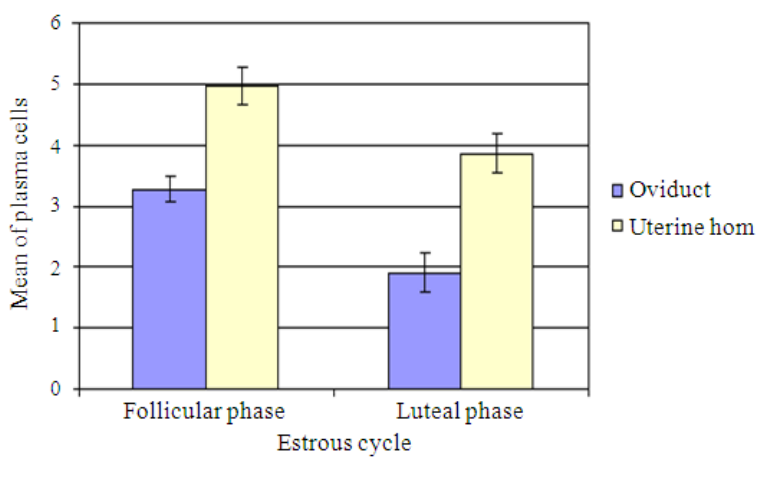

Fig. 3: Distribution of Plasma cells in the uterin horn and oviduct of reproductive tract of the ewes throughout the estrous cycle. Data are showed as the mean \pm SE $(n=6),(p<0.01)$ numbers of plasma cells within lamina propria of the oviduct and uterine horn

oviduct (A2, B2). They were also localized between the epithelial cells of the uterine and oviduct glands (A3, B3). Present in the stroma that supports the epithelial layer for uterine horn and oviduct (A2, B2).

The plasma cells populations within the lamina propria of the uterine horns and the oviduct during follicular and luteal phases of the ewes are showed in Fig. 3. The mean number of the plasma cells was significantly higher $(\mathrm{p}<0.01)$ in the uterine horn during follicular phase $(4.97 \pm 0.32 ; 95 \% \mathrm{CI}=-1.9$ to -0.2$)$ compared to the luteal phase $(3.87 \pm 0.30)$. In addition, the mean numbers of plasma cells in oviduct during follicular and luteal phase were $3.82 \pm 0.33$ and $1.90 \pm 0.21$, respectively. The difference was statistically significant $(\mathrm{p}<0.01 ; 95 \% \mathrm{CI}=-2.1$ to -0.5$)$.

\section{DISCUSSION}

In this study, we examined the relationship of the uterine S-IgA and plasma cells in tissues with the influence of the estrous cycle stages in ewes. We determined that the levels of S-IgA and values of plasma cells in the reproductive tract vary at different stages of the estrous cycle. The highest levels of S-IgA and numbers of plasma cells were recorded during follicular phase (under the estrogen hormone influence), while the lowest levels occurred during the luteal phase (under the progesterone hormone influence) of estrous cycle in ewes. It was well known, that during follicular phase, the female reproductive tract at the time around of the ovulation, the secretion of cervical gland is serous-type that facilitates coming in of the spermatozoa into the uterus. During luteal 
phase or pregnancy, the secretions of the cervical glands become more viscous, forming a plug of thickened mucous in the orifice of the cervix, thus, preventing the coming in of sperm and microorganisms into the uterus ${ }^{[13]}$. In sheep, one of the progesterone actions is to reduce numbers of specific populations of lymphocytes in the layers of uterine endometrium and hybridoma xenografts ${ }^{[17]}$. It also played role by hinders rejection or enhances survival of skin allografts placed within the uterine lumen ${ }^{[9]}$. This progesterone action may prevent immunological rejection of the newly attached fetus by the mother immune system ${ }^{[8]}$.

As ratiocination from the mentioned earlier, the female reproductive tract must be supported by the female immune system to encounter the invading of microorganism from the outer environmental during the relaxation period for the cervix, especially during the last stage of follicular phase when the female accept the male. Results of the current study are consistent with the previous researchers, where the increasing levels of uterine $\mathrm{S}-\operatorname{Ig} \mathrm{A}$ and amount of plasma cell occurred during follicular phase and decreased during the luteal phase. However, the current study presents a more specific data on the amount of uterine S-IgA and plasma cells during follicular and luteal phases.

Results of the study also showed that immune system level was enhanced during the follicular phase and decreased during the luteal phase of ewes. That agrees with previous studies done in ewes, cows and mares $^{[4,5,10,15,22,23]}$. Based on the result of this study and from the previous reports, it is confirm that the difference stages of estrous cycle have different uterine immune levels in ewes. The immune system during the follicular phase under estrogen influenced is highest its levels than luteal phase under progesterone influenced in ewes.

\section{REFERENCES}

1. Banks, W., 1993. Applied Veterinary Histology. 3rd Edn., Mosby Year Book, Saint Louis Missoury, ISBN: 10: 0801666104, pp: 527..

2. Brandtzaeg, P., 1974. Mucosal and glandular distribution of immunoglobulin components. Differential localization of free and bound Secretory Component (SC) in the secretory epithelial cells. J. Immunol., 112: 1553-1559. http://www.jimmunol.org/cgi/content/abstract/112/ 4/1553

3. Brandtzaeg, P., 1997. Mucosal immunity in the female genital tract. J. Reprod. Immunol., 36: 23-50. http://www.ncbi.nlm.nih.gov/pubmed/9430737
4. Brinsfield, T., H. Hawk and H. Righter, 1964. Interaction of progesterone and oestradiol on induced leukocytic emigration in the sheep uterus. J. Reprod. Fertil., 8: 293-296. DOI: 10.1530/jrf.0.0080293

5. Carson, R., D. Wolfe, P. Klesius, R. Kemppainen and C. Scanlan, 1988. The effects of ovarian hormones and ACTH on uterine defense to Coryebacterium pyogenes in cows. Theriogenology, 30: 91-97. DOI: 10.1016/0093691X(88)90266-X

6. Crowther, J., 2001. Systems in ELISA. The ELISA Guidebook: Methods in Molecular Biology. Humana Press, Totowa, New Jersey, ISBN: 0896037282, pp: 12-14.

7. Fisher, M., B. Nagy, H. Bazin and B. Underdown, 1979. Biliary transport of IgA: Role of secretory component. Proc. Natl. Acad. Sci. USA., 76: 2008-2012. http://www.ncbi.nlm.nih.gov/pubmed/287039

8. Hansen, P., 1998. Regulation of uterine function by progesterone-lessons from the sheep. J. Reprod. Immunol., 40: 63-79. http://www.ncbi.nlm.nih.gov/pubmed/9862257

9. Hansen, P., F. Bazer and E. Segerson, 1986. Skin graft survival in the uterine lumen of ewes treated with progesterone. Am. J. Reprod. Immunol. Microbiol., 12: 48-54.

http://www.ncbi.nlm.nih.gov/pubmed/3538916?do $\mathrm{pt}=\mathrm{Abstract}$

10. Hawk, H., T. Brinsfield, G. Turner, G. Whitmore and M. Norcross, 1964. Effect of ovarian status on induced acute inflammatory responses in cattle uteri. J. Vet. Res., 25: 362-366. http://www.ncbi.nlm.nih.gov/pubmed/14125900

11. Howard, C. and M. Reed, 1998. Unbiased Stereology: Three-Dimensional Measurement in Microscopy. BIOS Scientific Publishers Limited, United Kingdom, ISBN: 10: 0387915168, pp: 264.

12. Hussein, A., T. Newby and F. Bourne, 1983. Immunohistochemical studies of the local immune system in the reproductive tract of the sow. J. Reprod. Immunol., 5: 1-15. DOI: 10.1016/01650378(83)90016-5

13. Junqueira, L. and J. Carneiro, 2005. The Female Reproductive System. In: Basic Histology, 11th Edn., McGraw-Hill Companies, USA., ISBN: 0-07144116-6, pp: 435-451.

14. Kutteh, W., S. Prince, K. Hammond, C. Kutteh and J. Mestecky, 1996. Variations in immunoglobulins and $\operatorname{IgA}$ subclasses of human uterine cervical secretions around the time of ovulation. Clin. Exp. Immunol., 104: 538-542. DOI: 10.1046/j.13652249.1996.36742.x 
15. Lander Chacin, M., P. Hansen and M. Drost, 1990. Effect of stage of the estrous cycle and steroid treatment on uterine immunoglobulin content and polymorphonuclear leukocytes in cattle. Theriogenology, 34: 1169-1184. DOI: 10.1016/S0093-691X(05)80016-0

16. Lu, F., Z. Ma, T. Rourke, S. Srinivasan, M. McChesney and C. Miller, 1999. Immunoglobulin concentrations and antigen-specific antibody levels in cervicovaginal lavages of rhesus macaques are influenced by the stage of the menstrual cycle. Infect. Immun., 67: 6321-6328. http://www.pubmedcentral.nih.gov/articlerender.fc gi? artid=97036

17. Majewski, A. and P. Hansen, 2002. Progesterone inhibits rejection of xenogeneic transplants in the sheep uterus. Horm. Res., 58: 128-135. DOI: 10.1159/000063578

18. Perez-Martinez, M., J. Luna, R. Mena and M. Romano, 2002. Lymphocytes and T lymphocyte subsets are regionally distributed in the female goat reproductive tract: Influence of the stage of the oestrous cycle. Res. Vet. Sci., 72: 115-121. DOI: 10.1053/rvsc.2001.0532

19. Petrie, A. and P. Watson, 1999. Statistics for Veterinary and Animal Science. Iowa State Press, UK., ISBN: 10: 063205025X, pp: 144-146.

20. Ramadan, A., G. Johnson and G. Lewis, 1997. Regulation of uterine immune function during the estrous cycle and in response to infectious bacteria in sheep. J. Anim. Sci., 75: 1621-1632. http://jas.fass.org/cgi/reprint/75/6/1621
21. Ranchman, F., V. Casimira, A. Psychoyos and O. Bernard, 1983. Immunoglobulins in the mouse uterus during the estrous cycle. J. Reprod. Fertil., 69: 17-21. DOI: 10.1530/jrf.0.0690017

22. Roth, J., M. Kaeberle, L. Appell and R. Nachreiner, 1983. Association of increased estradiol and progesterone blood values with altered bovine polymorphonuclear leukocyte function. Am. J. Vet. Res., 44: 247-253.

http://www.ncbi.nlm.nih.gov/pubmed/6681945?do $\mathrm{pt}=\mathrm{Abstract}$

23. Washburn, S., P. Klesius, V. Ganjam and B. Brown, 1982. Effect of estrogen and progesterone on the phagocytic response of ovariectomized mares infected in utero with $\beta$-hemolytic streptococci. Am. J. Vet. Res., 43: 1367-1370. http://www.ncbi.nlm.nih.gov/pubmed/7103220?do $\mathrm{pt}=\mathrm{Abstract}$

24. Wira, C., J. Richardson and R. Prabhala, 1994. Endocrine Regulation of Mucosal Immunity: Effect of Sex-Hormones and Cytokines on the Afferent and Efferent Arms of the Immune System in the Female Reproductive Tract. In: Handbook of Mucosal Immunology, Ogra, P.L., J. Mestecky, M.E. Lamm, W. Strober, J.R. Mc Ghee and J. Bienestoc (Eds.). Academic Press, New York, ISBN: 0125247303, pp: 705-718. 